\title{
Nutritional Status of Day and Boarding Female Adolescent Secondary School Students in Warri South Local Government Area of Delta State
}

\author{
Kolawole Sunday Ekanah ${ }^{1,}$, , Agofure Otowve ${ }^{2}$, Edeta Rose $^{2}$ \\ ${ }^{1}$ Faculty of Health Sciences, National Open University, Benin Study Centre, Benin City, Nigeria \\ ${ }^{2}$ Department of Public and Community Health, Novena University, Ogume, Nigeria
}

Email address:

kolasunde@gmail.com (S. E. Kolawole), agofureotovwe@yahoo.com (O. Agofure), rosyedeta@yahoo.com (R. Edeta)

*Corresponding author

\section{To cite this article:}

Kolawole Sunday Ekanah, Agofure Otowve, Edeta Rose. Nutritional Status of Day and Boarding Female Adolescent Secondary School Students in Warri South Local Government Area of Delta State. Journal of Food and Nutrition Sciences. Vol. 5, No. 3, 2017, pp. 131-139. doi: $10.11648 /$ j.jfns.20170503.20

Received: April 4, 2017; Accepted: April 13, 2017; Published: May 25, 2017

\begin{abstract}
Nutrient intake during adolescence is of critical importance because this period is characterized by an exceptionally rapid rate of growth. The poor nutritional status of adolescents, especially girls, has important implications in terms of physical work capacity and adverse reproductive outcomes. Thus, a study on the nutritional patterns of adolescent girls is imperative to improve their growth rate and reproductive outcomes. Therefore, this study was designed to investigate the nutritional status of day and boarding students in public secondary schools in Warri South Local Government Area of Delta State. The study was a comparative cross sectional study which sampled a total of 326 students from secondary schools in Warri South L. G. A. of Delta State. A semi-structured questionnaire was self-administered to obtain information on respondents' socio-demographic characteristics, nutritional pattern and factors influencing adolescent nutrition. Descriptive statistics, Chi-square test and ANOVA were used to analyse the data with level of significance set at 0.05 . The results show that the mean age of the respondents was $12.27 \pm 1.79$ years with majority in the age bracket of between 10-15 years of age and more as day students $58.90 \%$ than boarding students $41.10 \%$. Assessment of the nutritional status of day and boarding students show that $11.20 \%$ of the boarding students were underweight as compared to $9.40 \%$ of the day students, $87.30 \%$ were of normal weight as compared to $80.70 \%$ of the day students. However, only $4.20 \%$ of the day students were overweight as compared to $1.50 \%$ of the boarding students and $5.70 \%$ of the day students were obese as compared to none among the boarding students. Factors that significantly influences the nutritional status of the students were mothers level of education and occupation, non-palatability of the food in the hostels and skipping of meals especially by the boarders $(\mathrm{P}<0.05)$. Therefore, concerted efforts should be made by all stakeholders in the education ministry (Government, School Authorities and Parents) to improve the meal of the students residing in the hostels in secondary schools nationwide; while parents should continually make it a duty to improve the meals of their children at home especially the adolescent girls who are still growing in order to enhance their physical work capacity, reproductive and pregnancy outcomes and birth weight.
\end{abstract}

Keywords: Nutritional Pattern, Day and Boarding, Adolescent, Students, Female

\section{Introduction}

Human nutrition refers to the provision of essential nutrient necessary to support human life and health. Poor nutrition is a chronic problem that is synonymous to poverty and it occurs due to poor nutritional understanding and practice. Lack of proper nutrition contribute to lower academic performance, low score, and eventually less successful students and a less productive and competitive economy [1]. A good nutritional status means that one have a healthy body composition without physical sign of nutritional deficiency, good blood working rate, adequate protein in store and other vital nutrients [2].

The World Health Organization define adolescent as any 
person between the ages of $10-19$ years [3]. Adolescent is a particular unique period in life because it is a time of intense physical, psychological, and cognitive development [4]. The foundation of good health and sound mind is laid during this period. This age is considered a dynamic period of growth and development [5]. Adolescent may represent a window of opportunity to prepare nutritionally for a healthy adult life [6].

Under nutrition among adolescent girls is a major public health problem leading to impaired growth [7]. For instance in Bangladesh a large number of adolescent girls suffered from various degrees of nutritional disorders [8]. Furthermore, previous study done in India found that majority of adolescent girls were under nourished [9] and nutritional difficulties have been shown to have consequences especially on adolescent girls [10]. Consequently, if the nutritional needs of adolescent girls are not met they are likely to give birth to undernourished children, thus transmitting undernourishment to future generation [11]. The nutritional status of adolescent girls, the future mothers, contributes to the nutritional status of the community [12].

The prevalence of malnutrition particularly among adolescents is an alarming global problem affecting about one third of the world population. Malnutrition in school girls remains a major public health and social problem in Nigeria [13] as mortality among Chronic Energy Deficiency (CED) individual in Nigeria who are mildly, moderately and severely underweight are 40, 140 and $150 \%$ greater, respectively than rates among non chronic energy deficiency individuals [14]. Students in boarding school may be at higher risk of developing nutrient deficiencies compared to those in non-boarding schools probably due to financial constraint in running boarding facilities and some may not like the food on the menu list of the school. Consequently, obtaining almost all their energy and major nutrients from snacks. This was further affirmed by a study in South-West Nigeria where boarding students showed lower nutritional intake than their day counterpart in Secondary schools in Owo Ondo State, South-Western Nigeria [15]. Current research to investigate the pattern of nutrition among day and boarding adolescent secondary school girls is therefore necessary to inform and drive efficient policies that would reduce the effect of malnutrition in Warri South Local Government Area of Delta State, Nigeria.

\section{Material and Method}

\subsection{Study Design}

The study design adopted in this study was a comparative cross sectional survey design.

\subsection{Scope of the Study}

The scope of this study focused on the nutritional status of adolescent girls in secondary schools (day and boarding) in Warri South Local Government Area Delta State.

\subsection{Description of the Study Area}

The research was carried out in Warri South Local Government Area. It's headquarter is in the city of Warri. The area is predominately riverine with large expanses of mangrove forest and has a land area of approximately, 1520 square meter. It has an area of $633 \mathrm{~km}^{2}$ and a population of 303,417 at the 2006 census the postal code of the area.

\subsection{Inclusion Criteria}

The inclusion criteria includes female adolescents, secondary schools both state and federal with a mixture of both boarding and day.

\subsection{Exclusion Criteria}

The exclusion criteria were male adolescents, private schools and schools with only day or boarding facilities.

\subsection{Sample Procedure}

A multistage sampling technique was employed. Three schools were selected from the twelve Government secondary Schools because they are the only schools with boarding and day facilities in Warri South Local Government Area.

Simple random sampling was used to select student from different arms in junior and senior secondary school. Anthropometric measurement was carried out using the standard technique; Height, Weight and Body Mass Index was calculated using the standard method [16].

\subsection{Sample Size Determination}

N-2994 (Population of the schools) O-0.05 (Expected Frequency)

$$
\begin{gathered}
\text { Sample size }=\frac{\mathrm{N}}{1+\mathrm{NO} 2} \\
\text { Sample Size }=\frac{2994}{1+\left(2994 \times 0.05^{2}\right)} \\
\text { Sample Size }=\frac{2994}{1+7.485} \\
\text { Sample Size }=\frac{2994}{8.485} \\
\text { Sample Size }=353
\end{gathered}
$$

\subsection{Instrument for Data Collection}

A semi-structured questionnaire was used to obtain information from the respondents. The questionnaire obtained information on respondents' socio-demographic characteristics, Nutritional pattern of the students, Factors that influences adolescent nutrition and suggestion on how adolescent nutrition can be improved. In addition, Anthropometric measurement of height and weight were also done using standard calibrated instruments. 


\subsection{Method for Data Analysis}

Data generated were analysed using SPSS (Statistical Product and Service Solution) version 15.0 manufactured by IBM incorporated. Descriptive statistics were used to evaluate frequency distribution, while Chi-Square test and ANOVA were used to determine associations between variables of interest with level of significance set at $\mathrm{P}<0.05$. Furthermore, Body Mass Index was calculated and used to determine the nutritional status of the respondents.

\subsection{Ethical Issue}

Ethical clearance for the study was obtained from the Department of Public and Community Health, Novena University. Also permission was obtained from the Chief Inspector of Education, Ministry of Basic and Secondary Education Warri South Local Government Area.

\section{Results}

As shown in table 1 below, more than half of the day students $174(53.40 \%)$ were between the ages $10-15$ years while $117(35.90 \%)$ of the boarding students were between the ages $10-15$ years. Similarly, almost half of the day students $161(49.40 \%)$ were in JSS class, while 91(27.90\%) of the boarding students were in JSS class. Furthermore, $101(31.0 \%)$ of the day students and $66(20.20 \%)$ of the boarding students have been in the school for only a year, while $52(16.0 \%)$ of the day students and $35(10.70 \%)$ of the boarding students have been in the school for 2 years respectively. The overall mean age for both day and boarding students was $12.27 \pm 1.79$ years.

Table 1. Socio-demographic characteristics of the respondents.

\begin{tabular}{lllll}
\hline \multirow{2}{*}{ Variable } & \multicolumn{3}{l}{ Day } & \multicolumn{3}{l}{ Boarding } \\
\cline { 2 - 5 } & $\mathbf{F ~ ( 1 9 2 )}$ & $\mathbf{\%}$ & $\mathbf{F ~ ( 1 3 4 )}$ & $\mathbf{\%}$ \\
\hline Age & & & & \\
$10-15$ & 174 & 53.40 & 117 & 35.90 \\
$16-20$ & 18 & 5.50 & 17 & 5.20 \\
Class of the respondents & & & & \\
JSS & 161 & 49.40 & 91 & 27.90 \\
SSS & 31 & 9.50 & 43 & 13.20 \\
How long have you been & & & & \\
in this school & & & & \\
1 & 101 & 31.0 & 66 & 20.20 \\
2 & 52 & 16.0 & 35 & 10.70 \\
3 & 10 & 3.10 & 10 & 3.10 \\
4 & 22 & 6.70 & 19 & 5.80 \\
5 & 6 & 1.80 & 4 & 1.20 \\
6 & 1 & 0.30 & 0 & 0.0 \\
Religion & & & & \\
Christian & 188 & 57.7 & 132 & 40.50 \\
Muslim & 4 & 1.2 & 2 & 0.60 \\
Tribe & & & & \\
\hline
\end{tabular}

\begin{tabular}{lllll}
\hline \multirow{2}{*}{ Variable } & \multicolumn{3}{c}{ Day } & \multicolumn{3}{l}{ Boarding } \\
\cline { 2 - 5 } & $\mathbf{F ~ ( 1 9 2 )}$ & $\mathbf{\%}$ & $\mathbf{F ~ ( 1 3 4 )}$ & $\mathbf{\%}$ \\
\hline Urhobo & 72 & 22.10 & 42 & 12.90 \\
Itsekiri & 41 & 12.60 & 12 & 3.70 \\
Ijaw & 19 & 5.80 & 8 & 2.50 \\
Benin & 19 & 5.80 & 23 & 7.10 \\
Igbo & 30 & 9.20 & 43 & 13.20 \\
Efik/Ibibio & 0 & 0.0 & 3 & 0.90 \\
Yoruba & 11 & 3.40 & 0 & 0.0 \\
Isoko & 0 & 0.0 & 3 & 0.90 \\
\hline
\end{tabular}

Overall mean age of the students: $12.27 \pm 1.79$

According to figure 1 below, more than half of the respondents $58.90 \%$ were day students, while $41.10 \%$ were boarding students respectively.

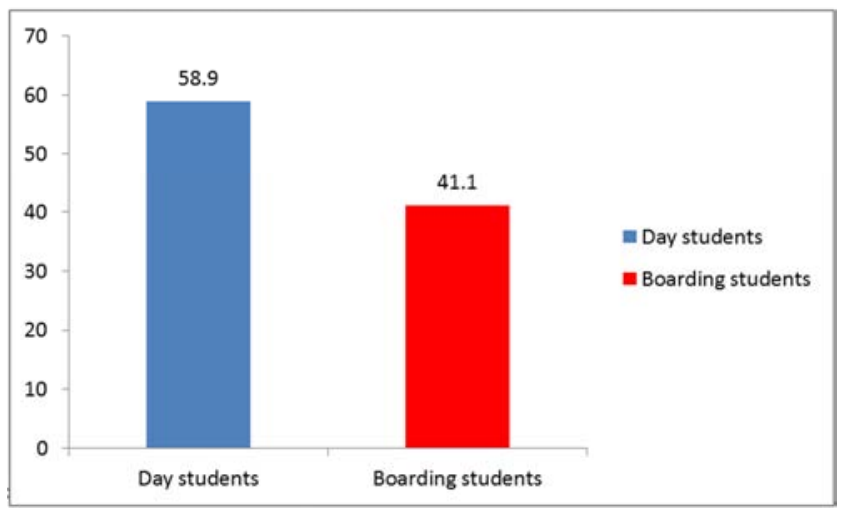

Figure 1. School status of the respondents.

The nutritional pattern of the respondents shows that 119 $(36.50 \%)$ of the day students and $47(14.40 \%)$ of the boarding students ate beans at least twice a week, while 21 $(6.40 \%)$ of day students and $38(11.70 \%)$ of boarding students ate beans more than 4 times a week respectively. Furthermore, more than half of the day students 180 $(55.20 \%)$ and two third of the boarding students 108 $(33.10 \%)$ affirmed that all their meals contain either meat/fish/egg, while 55 (16.90\%), $45(13.80 \%)$ and 42 $(12.90 \%)$ of the day students said they take fruit 2 times, 3 times and daily respectively; and 21 (6.40\%), 11 (3.40\%) and $9(2.80 \%)$ of the boarding students said they take fruit once, 2 times and 3 times respectively. In addition, majority of the boarding students $110(82.10 \%)$ affirmed that their school meals adhered to what is written on the menu list, while $87(64.90 \%)$ of the boarding students thinks the school kitchen staff should be in charge of sharing food and $128(95.50 \%)$ said they were fed 3 times a day in the school (Table 2). 
Table 2. Nutritional pattern of the students residing at home or hostel.

\begin{tabular}{|c|c|c|c|c|}
\hline \multirow{2}{*}{ Variable } & \multicolumn{2}{|l|}{ Day } & \multicolumn{2}{|c|}{ Boarding } \\
\hline & F (192) & $\%$ & F (134) & $\%$ \\
\hline \multicolumn{5}{|c|}{ How many times do you eat beans in a week } \\
\hline 2 times & 119 & 36.50 & 47 & 14.40 \\
\hline 3 times & 22 & 6.70 & 32 & 9.80 \\
\hline 4 times & 18 & 5.50 & 15 & 4.60 \\
\hline More than 4 times & 21 & 6.40 & 38 & 11.70 \\
\hline Not at all & 11 & 3.40 & 2 & 0.60 \\
\hline Once & 1 & 0.30 & 0 & 0.0 \\
\hline \multicolumn{5}{|c|}{ Does all your meal contain either of the following meat/fish/egg } \\
\hline Yes & 180 & 55.20 & 108 & 33.10 \\
\hline No & 12 & 3.70 & 26 & 8.0 \\
\hline \multicolumn{5}{|c|}{ Does your school adhere to what is written on the menu list } \\
\hline Yes & & & 110 & 82.10 \\
\hline No & & & 24 & 17.90 \\
\hline \multicolumn{5}{|c|}{ How many times do you take fruit daily weekly } \\
\hline Once & 33 & 10.10 & 21 & 6.40 \\
\hline 2 times & 55 & 16.90 & 11 & 3.40 \\
\hline 3 times & 45 & 13.80 & 9 & 2.80 \\
\hline Daily & 42 & 12.90 & 5 & 1.50 \\
\hline None of the above & 17 & 5.20 & 88 & 27.0 \\
\hline \multicolumn{5}{|c|}{ How many times do you eat vegetable weekly } \\
\hline Once & 39 & 12.0 & 27 & 8.30 \\
\hline 2 times & 59 & 18.10 & 51 & 15.60 \\
\hline 3 times & 45 & 13.80 & 16 & 4.90 \\
\hline 4 times and above & 27 & 8.30 & 22 & 6.70 \\
\hline None of the above & 22 & 6.70 & 18 & 5.50 \\
\hline \multicolumn{5}{|c|}{ Does your school/parent have garden } \\
\hline Yes & 70 & 21.50 & 66 & 20.20 \\
\hline No & 122 & 37.40 & 68 & 20.90 \\
\hline \multicolumn{5}{|c|}{ Who do you think should in charge of sharing food } \\
\hline Students & & & 18 & 13.40 \\
\hline Kitchen & & & 87 & 64.90 \\
\hline Dinning prefect & & & 29 & 21.60 \\
\hline \multicolumn{5}{|c|}{ Are the meals delicious } \\
\hline Yes & & & 45 & 33.60 \\
\hline No & & & 89 & 66.40 \\
\hline \multicolumn{5}{|c|}{ Are the meals adequate } \\
\hline Yes & & & 41 & 30.60 \\
\hline No & & & 93 & 69.40 \\
\hline \multicolumn{5}{|c|}{ How many times are you fed in a day } \\
\hline 2 times & & & 1 & 0.70 \\
\hline 3 times & & & 128 & 95.50 \\
\hline 4 times & & & 5 & 3.70 \\
\hline \multicolumn{5}{|c|}{ Are the meals served on time } \\
\hline Yes & & & 81 & 60.40 \\
\hline No & & & 53 & 39.60 \\
\hline \multicolumn{5}{|c|}{ Are your meals balanced } \\
\hline Yes & & & 50 & 37.30 \\
\hline No & & & 84 & 62.70 \\
\hline
\end{tabular}

According to table 3 below, more of the day 127 (39.0\%) and boarding $83(25.50 \%)$ students had literate parents, while $65(19.90 \%)$ of the day students and $83(25.50 \%)$ of the boarding students mothers' were private/government employees respectively. In addition, $96(29.40 \%)$ of the day students and $92(28.20 \%)$ of the boarding had more than five persons residing in their various houses, while less than two third $81(60.40 \%)$ of the boarding students says their boarding fee is not equal to the food they eat in a session and the reasons given were that because the food they eat is not enough $52(66.70 \%)$, the food is always watery and the food is not delicious $18(23.10 \%)$ respectively. Furthermore, 108 $(33.10 \%)$ of the day students says they have not suffered any illness in the past two weeks, while $92(28.20 \%)$ of the boarding students affirmed to have suffered illness in the past two weeks. The type of illness respondents highlighted to have suffered in the past two weeks includes malaria, stomach ache and cough/catarrh. 
Table 3. Factors that influence adolescent nutrition

\begin{tabular}{|c|c|c|c|c|}
\hline \multirow{2}{*}{ Variable } & \multicolumn{2}{|l|}{ Day } & \multicolumn{2}{|c|}{ Boarding } \\
\hline & F (192) & $\%$ & F (134) & $\%$ \\
\hline \multicolumn{5}{|l|}{ What is your father's level of education } \\
\hline Can't read/write & 55 & 16.90 & 33 & 24.60 \\
\hline Primary & 0 & 0.0 & 5 & 3.70 \\
\hline Secondary & 10 & 3.10 & 13 & 9.70 \\
\hline College/University & 127 & 39.0 & 83 & 61.90 \\
\hline \multicolumn{5}{|l|}{ What is the level of education of your mother } \\
\hline Primary & 2 & 0.60 & 2 & 19.40 \\
\hline Secondary & 18 & 5.50 & 5 & 3.70 \\
\hline College/University & 124 & 38.0 & 98 & 73.10 \\
\hline \multicolumn{5}{|l|}{ Occupation of mother } \\
\hline Housewife & 9 & 2.80 & 3 & 2.20 \\
\hline Trader & 67 & 20.60 & 29 & 21.60 \\
\hline Private/Government employee & 65 & 19.90 & 83 & 61.90 \\
\hline Jobless & 4 & 1.20 & 1 & 0.70 \\
\hline Businesswoman & 13 & 4.0 & 4 & 3.0 \\
\hline Tailoring & 3 & 0.90 & 2 & 1.50 \\
\hline Doctor & 1 & 0.30 & 0 & 0.0 \\
\hline Teacher & 7 & 2.10 & 5 & 3.70 \\
\hline \multicolumn{5}{|l|}{ How many are you in your house } \\
\hline Less than five & 96 & 29.40 & 38 & 28.40 \\
\hline More than 5 & 96 & 29.40 & 92 & 68.70 \\
\hline Exactly 5 & 0 & 0.0 & 4 & 3.0 \\
\hline \multicolumn{5}{|l|}{ Does the boarding fee equal to the food you eat in a session } \\
\hline Yes & & & 53 & 39.60 \\
\hline No & & & 81 & 60.40 \\
\hline \multicolumn{5}{|l|}{ If no to question } \\
\hline Because we do not eat enough food & & & 52 & 66.70 \\
\hline Because the food is always watery & & & 5 & 6.40 \\
\hline Because the food is not delicious & & & 18 & 23.10 \\
\hline Yes & 84 & 25.80 & 92 & 68.70 \\
\hline No & 108 & 33.10 & 42 & 31.30 \\
\hline \multicolumn{5}{|l|}{ If yes tick the condition } \\
\hline Malaria & 18 & 10.20 & 19 & 10.80 \\
\hline Stomach ache & 12 & 6.80 & 30 & 17.0 \\
\hline Cough/Catarrh & 54 & 30.70 & 30 & 17.0 \\
\hline Glaucoma & 0 & 0.0 & 1 & 0.60 \\
\hline Body pain and sore throat & 0 & 0.0 & 8 & 4.50 \\
\hline Typhoid fever & 0 & 0.0 & 4 & 2.30 \\
\hline \multicolumn{5}{|l|}{ Do you skip meals } \\
\hline Yes & 80 & 24.50 & 80 & 41.70 \\
\hline No & 112 & 34.40 & 54 & 58.30 \\
\hline \multicolumn{5}{|l|}{ If yes to question } \\
\hline I don't eat much & 3 & 1.80 & 4 & 2.40 \\
\hline Because I don't like the food & 26 & 15.80 & 36 & 21.80 \\
\hline Because the food is not delicious \& nutritious & 0 & 0.0 & 14 & 8.50 \\
\hline Sometimes I might not be hungry & 30 & 18.20 & 8 & 4.80 \\
\hline Because of extra lessons \& other school activities & 10 & 6.10 & 14 & 8.50 \\
\hline Because it keeps me fit & 2 & 1.20 & 0 & 0.0 \\
\hline Whenever I am angry & 4 & 2.40 & 0 & 0.0 \\
\hline If the food is delayed \& not served on time & 5 & 3.0 & 0 & 0.0 \\
\hline Sometimes before I get to the dining hall the food is finished & 5 & 3.0 & 4 & 2.40 \\
\hline \multicolumn{5}{|l|}{ Do you know that skipping meals can make you fall sick } \\
\hline Yes & 180 & 55.20 & 121 & 37.10 \\
\hline No & 12 & 3.70 & 13 & 4.0 \\
\hline Does your culture/religion forbid any food on the menu list & & & & \\
\hline Yes & 6 & 1.80 & 0 & 0.0 \\
\hline No & 186 & 57.10 & 134 & 41.10 \\
\hline If yes to question 30 why & & & & \\
\hline Because it makes me sick & 6 & 100 & & \\
\hline
\end{tabular}


Table 4 show the suggestions made by both the day and boarding students on how the government can improve adolescent nutrition includes; assisting the schools by providing more farm produce, increasing the funds for nutrition of adolescents, improving the contents of the food and monitoring the kind of food been served in the school. Furthermore, suggestions on how the school can improve adolescent nutrition by both the day and boarding students includes; providing good and adequate food, ensuring adequate supply of vegetables and fruits, forming partnership with the government and schools should judiciously make use of the students school fees to improve their nutrition. In addition, suggestions on how the family can improve adolescents nutrition by both the day and boarding students includes; providing food for their children, assisting the school and the government, making sure their children eat enough and providing variety of food for their children.

Table 4. Suggestion of how adolescent nutrition can be improved.

\begin{tabular}{|c|c|c|c|c|}
\hline \multirow{2}{*}{ Variable } & \multicolumn{2}{|l|}{ Day } & \multicolumn{2}{|c|}{ Boarding } \\
\hline & F (192) & $\%$ & F (134) & $\%$ \\
\hline \multicolumn{5}{|l|}{ Suggest ways the government can improve adolescent nutrition } \\
\hline By increasing the funds for the nutrition of adolescents & 77 & 23.60 & 36 & 11.0 \\
\hline They should assist the schools by providing more farm produce & 79 & 24.20 & 51 & 15.60 \\
\hline They should try to improve the contents of the food & 18 & 5.50 & 4 & 1.20 \\
\hline By monitoring the kind of food been served in the school & 7 & 2.10 & 23 & 7.10 \\
\hline Farm produce should be made cheaper in the market & 3 & 0.90 & 15 & 4.60 \\
\hline \multicolumn{5}{|l|}{ Suggest ways the school can improve adolescent nutrition } \\
\hline By providing good \& adequate food & 62 & 19.0 & 33 & 10.10 \\
\hline They should ensure adequate supply of vegetables $\&$ fruits & 50 & 15.30 & 43 & 13.20 \\
\hline They should form partnership with government and encourage them to always assist the school & 31 & 9.50 & 31 & 9.50 \\
\hline By judiciously making use of the students school fees to improve their nutrition & 14 & 4.30 & 17 & 5.20 \\
\hline By making sure that schools sell less of junk food & 18 & 5.50 & 3 & 0.90 \\
\hline Students should be taught on the importance of balanced diet to their health & 8 & 2.50 & 3 & 0.90 \\
\hline \multicolumn{5}{|l|}{ Suggest ways the family can improve adolescent nutrition } \\
\hline By providing food for their children & 68 & 20.90 & 39 & 12.0 \\
\hline By making sure their children eat enough & 33 & 10.10 & 43 & 13.20 \\
\hline They should support the school and the government & 54 & 16.60 & 21 & 6.40 \\
\hline They should provide variety of food for their children & 21 & 6.40 & 22 & 6.70 \\
\hline There should be prompt payment of salaries so parents can provide adequately for the family & 9 & 2.80 & 4 & 1.20 \\
\hline Families should make sure children do not skip meals & 7 & 2.10 & 5 & 1.50 \\
\hline
\end{tabular}

As shown in figure 2 below, $83.40 \%$ of the respondents had normal weight, while $10.10 \%, 3.40 \%$ and $3.10 \%$ of the respondents were underweight, obese and overweight respectively.



Figure 2. Nutritional status of the day and boarding students according to BMI.

The results from table 5, shows that majority of the female students who were day $155(47.50 \%)$ and boarding $117(35.90 \%)$ maintained a normal weight. It also shows a significant relationship between the students who were day and boarding and their nutritional status according to BMI $(\mathrm{P}<0.05)$. Therefore, we will reject the null hypothesis which says there is no significant difference between the students that were day or boarding and their nutritional status. 
Table 5. Relationship between adolescent girls residing at home and the hostel and their nutritional status according to BMI.

\begin{tabular}{llllll}
\hline \multirow{2}{*}{ BMI } & Status of the students & \multirow{2}{*}{ X2 } & \multirow{2}{*}{ df } & \multirow{2}{*}{ P-value } \\
\cline { 2 - 5 } & Day & Boarding & 10.185 & 3 & 0.017 \\
\hline Underweight & $18(5.50 \%)$ & $15(4.60 \%)$ & & \\
Normal weight & $155(47.50 \%)$ & $117(35.90 \%)$ & & \\
Overweight & $8(2.50 \%)$ & $2(0.60 \%)$ & & & \\
Obesity & $11(3.40 \%)$ & $0(0.0 \%)$ & & \\
\hline
\end{tabular}

In table 6 below, the F-value is 1.023 and the significance is 0.313 ; that is the probability of getting an F value of 1.023 , if the hypothesis is true is 0.313 . Since this probability is more than 0.05 , we will therefore not reject the null hypothesis and conclude that the ages of the students did not have a significant influence on their nutritional status according to BMI.

Table 6. ANOVA table showing the relationship between the ages of the students and their nutritional status according to BMI.

\begin{tabular}{llllll}
\hline & Sum of squares & df & Mean square & F & P-value \\
\hline Between groups & 20.424 & 1 & 20.424 & 1.023 \\
Within groups & 6467.306 & 324 & 19.961 & \\
Total & 6487.730 & 325 & & \\
\hline
\end{tabular}

\section{Discussion}

\subsection{Socio-demographic Characteristics}

According to the findings, the mean age of the respondents was $12.27 \pm 1.79$ years with majority in the age bracket of between 10-15 years of age and more as day students $58.90 \%$ than boarding students $41.10 \%$. This is similar to the study in Accra Ghana, where non-boarding students were more than boarding students [17]. Age has been shown to be an important determinant of the nutritional status of adolescents. However, the study did not show any significant relationship between the age of both the day and boarding students and their nutritional status according to their Body Mass Index (BMI) classification. This finding is similar to a previous study among female adolescents in Bedelle town in Ethiopia which did not find any significant difference between the ages of the girls and their nutritional status according to BMI classification [18].

\subsection{Nutritional Pattern of Both Day and Boarding Students}

The overall nutritional status shows that majority $83.40 \%$ of both day and boarding students were of normal weight, while $10.10 \%$ were underweight and few $3.40 \%$ were obese. This is different from the findings of the study in Bangladesh where more of the adolescent girls were underweight [19]; but similar to the study in Accra Ghana where most of the students had normal weight [17]. Furthermore, assessment of the nutritional status of both the day and boarding students show that $11.20 \%$ of the boarding students were underweight as compared to $9.40 \%$ of the day students, $87.30 \%$ were of normal weight as compared to $80.70 \%$ of the day students. However, only $4.20 \%$ of the day students were overweight as compared to $1.50 \%$ of the boarding students and $5.70 \%$ of the day students were obese as compared to none among the boarding students. The relationship between the day and boarding students and their nutritional status was statistically significant $(\mathrm{P}=0.017)$ with boarding students tending to be more underweight and normal weight than their day counterpart residing at home that tend to be more overweight and obese.

The findings show that both the day and boarding students consumes some amount of protein such as beans, meat, fish and egg per week. This finding is different from the study in Bangladesh where adolescent girls did not consume much of proteinous food such as meat, egg and milk per week [20]. This consumption of protein reflected in their BMI classification with most of them showing normal weight. Also there was a significant difference between the number of times the day students ate beans and their nutritional status $(\mathrm{P}=0.01)$, while there was no significant difference between the number of times the boarding students ate beans and their nutritional status $(\mathrm{P}=0.198)$. Similarly, the day students understandably consumed more of fruit and vegetable than the boarding students. This is because they reside at home and they are expected to consume it more than the boarding students whose meal is more regimented. This finding was also different from the study in Bangladesh [20]. In the same vein there was a significant difference between the number of times both day and boarding students took fruit weekly and their nutritional status according to BMI classification $(\mathrm{P}=0.000)$.

In addition, most of the boarding students affirmed that their meals were not delicious, adequate and balanced, thus making some of them to skip meals which might affect their health and studies. However, most of the students asserted that they were fed three times daily which is similar to previous study in Ethiopia [18].

\subsection{Factors That Influence Adolescent Nutrition}

There was no significant difference between fathers level of education of both day and boarding students and their nutritional status respectively $(\mathrm{P}=0.138, \mathrm{P}=0.887)$. However, there was a significant difference between mothers level of education of day students and their nutritional status according to $\mathrm{BMI}$ classification $(\mathrm{P}=0.013)$ and not with the boarding students $(\mathrm{P}=0.096)$. Furthermore, there was no 
significant difference between mothers occupation of the boarding students and their BMI $(\mathrm{P}=0.066)$, but there was a significant difference between mothers occupation of the day students and their BMI $(\mathrm{P}=0.000)$. This result corroborates the role mothers play in the growth and development of their children at home. This finding is similar to previous studies in Bangladesh [21]. In the same vein family size had no significant difference with the nutritional status of both the day and boarding students $(\mathrm{P}=0.111)$. This finding was different from the study in Ethiopia where family size was significant with nutritional status of adolescent girls [18]. Some of the day and boarding students have suffered some form of illness such as malaria, stomach ache, cough/catarrh in the two weeks preceding the study. This is in line with the studies in Ethiopia and Bangladesh [18], [19]. Some of the boarding students skip meals more as compared to their day counterpart. This is not surprising as many complained of the food not been nutritious and delicious enough. This finding is also in line with the study in Ethiopia [18]. However, unlike the study in Bangladesh almost all the day and boarding students do not have taboo for any food [21].

\section{Conclusion}

The findings show that both the day and boarding students had normal weight. However, the boarding students tend to be more underweight, while the day students tend to be overweight and obese. In addition, the boarding students complained of their meal not being adequate and delicious and some of them do skip meals thus leading to common ailments among them. Therefore, concerted efforts should be made by all stakeholders in the education industry (Government, School Authorities and Parents) to improve the meal of the students residing in the hostels in secondary schools nationwide; while parents should continually make it a duty to improve the meals of their children at home especially the adolescent girls who are still growing in order to enhance their physical work capacity, reproductive and pregnancy outcomes and birth weight.

\section{References}

[1] Janiszewski, S. (2011) The science of starvation: How long can human survive without Food or Water. The Public Library of Science, University of Minnesota Press.

[2] Susan Thomas. (2015) Nutrition Status and Weight Loss. Retrieved from: www.livestrong.com.

[3] World Health Organisation (2005) Nutritional in adolescenceissues and challenges for the health sector. Issues in adolescent health and development. pp. 1-2.

[4] Shahid A, Siddiqui, FR, Bhatti, MA, Ahmed M, Khan MW. (2009) Assessment of Nutritional Status of Adolescent College Girls at Rawalpindi. Annals. 15 (1): 11 - 16.

[5] Uddin JM, Nag KS, Sil, KS. (2015) Anthropometric Assessment of Nutritional Status of Adolescents in Rural School of Unokoti District of Tripura. North-East India.
Anthropologist. 19(1): 277-284.

[6] Kumar N, Shekhar C, Kumar P, Kundu AS. (2007) Kuppusway's socio-economic status scale-updating for 2007. Indian J of Pediatrics. 74: 1131-1132.

[7] Kalhan M, Vashisht BM, Kumar V, Sharma S. (2010) "Nutritional status of adolescent girls of rural Haryana" The Internet J of Epidemiology. 8 (1): $211-216$.

[8] Kabir Y, Shahjalal MH, Saleh F, Obaid W. (2010) Dietary pattern nutritional status, anaemia and anaemia-related knowledge in urban adolescent college girls of Bangladesh. J Park Med. Assoc. 60 (8): 633-638.

[9] Patanwar P, Sharma KKN. (2013) Nutritional Status in Kurmi Adolescent Girls of Raipur City Chhtattisgarh: International Journal of Scientific and Research Publications. 3 (1): 1 - 6.

[10] Popkin BM, Horton S, Kim S, Maha A, Shuigo J. (2001) Trends in diet, nutritional status and diet related communicanle diseases in China and India: The economic costs of the nutrition transition. Nutr Rev Paediatr Indones. 59: 379-390.

[11] Mulugeta A, Hagos F, Stoecker B, Kruseman G, Linderhof V, Abraha Z, Yohannes M, Samuel GG. (2009) Nutritional Status of Adolescent Girls from Rural Communities of Tigray, Northern Ethiopia. Ethiopian Journal of Health Development. 23 (1): $5-11$.

[12] Venkaiah K, Damayanti K, Nayak MU, Vijayaraghavan. (2002) Diet and nutritional status of rural adolescents in India. Eu J ClinNutr. 56: 1119-1125.

[13] Akinyemi O, Ibraheem AG. (2009) Assessment of Nutritional Status of Queens College Students of Lagos State, Nigeria. Pakistan Journal of Nutrition. 8(7): 937-939.

[14] Rotimi C, Okosun I, Johnson L, Owoaje E, Lawoyin T, Asuzu M, Cooper C. (1999) The distribution and mortality impact of chronic energy deficiency among adult Nigerian men and women. Eur. J. Clin. Nutr. Res. 18: 351-379.

[15] OpeyemiBolajoko GA, Ogundahunsi OF, Odugbemi BA, OlanikeAlakuro. (2014) Nutrient Adequacy of Foods Eaten by Students Attending Boarding and Day Secondary Schools in Owo. Current Research in Nutrition and Food Science. 2(2): 84-87.

[16] Body Mass Index of Adolescent www.skillsyouneed.com/ps/bmi.html Assessed May 10th 2016.

[17] Intiful DF, Ogyiri L, Asante M, Mensah AA, Steele Dadzie KR, Boateng L. (2013) Nutritional Status of Boarding and Non Boarding Children in selected schools in the Accra Metropolis. Journal of Biology, Agriculture and Healthcare. 3 (7): $156-163$.

[18] Tsedeke W, Wakjira A, Dagnie M, Firew Y, Fedasa A, Fufa D, Tadesse, Eyasu E. (2014) Nutritional Status of Adolescent Girls Living in Southwest of Ethiopia, Food Science and Quality Management. 34: 58 - 64.

[19] Hossain GM, Sarwar MD, Rahman M, Shakh MA, Rouf S, Ud- Daula R, Hossain S. (2013) A study on nutritional status of the adolescent girls at Khagrachhari district in Chittagong hill tracts, Bangladesh, American Journal of Life Sciences. 1(6): 278-282. doi: 10.11648/j.ajls.20130106.17. 
[20] Nurul A, Swapan KR, Tahmeed AM, Shamsir A. (2010) Nutritional Status, Dietary Intake, and Relevant Knowledge of Adolescent Girls in Rural Bangladesh, J Health Popul Nutr. 28(1): 86-94.

[21] Mosarrof Hossain GM, TanvirSarwarMd, HafizurRahman M,
Shakh M. A. Rouf, SalimRaza, AsadUd- Daula, SabirHossain. (2013) A study on nutritional status of the adolescent girls at Khagrachhari district in Chittagong hill tracts, Bangladesh, American Journal of Life Sciences. 1(6): 278-282. doi: 10.11648/j.ajls.20130106.17. 